\title{
Contribution of the Geographic Information System (GIS) and the Analytical Hierarchy Process (AHP) in the Management of Worn Water and Deposit in the District of Abobo, Abidjan, Côte d'Ivoire: Case of Avocatier-Agnissankoi
}

\author{
Kanohin Fulvie Epse Otchoumou ${ }^{1}$, Konan Béhibro Ange-Delon ${ }^{2}$, Kokoré Ama Jeanne-d'Arc ${ }^{3}$ \\ ${ }^{1,2,3}$ Laboratory Geosciences and Environment, University Nangui Abrogoua, Abidjan, Côte d'Ivoire
}

\begin{abstract}
The present study aimed to determine the impact of the management of worn water and deposit on health and environment. An investigation was carried out near 642 houses of Avocatier-Agnissankoi, followed by an observation campaign of the operation of the drainage systems. The individual Cleansingswith the septic tanks are dominant (autonomous Cleansing). Worn and winnow waters resulting from the houses had any treatment and are rejected into the nature. That involves a degradation of the environment of life and the proliferation of hydrous diseases. The use of the geographic information system (GIS) and the Analytical Hierarchy Process (AHP) allow recording the level of cleansing through the cartography of the management of worn water and deposit. The good cover class of cleansing occupies 12, 84 PC of the study zone and is in the North of "Belle-cité. The worn water and deposit drainage of the other suburbs is carried out in great majority by traditional lost melt latrines whose pit is carried out by fortune shaft sinkers. This pollution, generated by the anthropic activities, presents a serious danger for the public health.
\end{abstract}

Keywords: Worn water, Deposit, Autonomous cleansing, Geographic Information System (GIS), Analytical Hierarchy Process (AHP), Côte d'Ivoire.

\section{Introduction}

In the large African cities, several factors make difficult the control of the management of the urban cleansing and the access to drinking water. The strong demographic growth (more than $5 \%$ per annum on average in the cities), is accompanied by an anarchistic space development which escapes any control from the authorities. The populations settle without having the possibility of reaching the urban services [12]. Thus, in these cities, the half only of the needs in drinking water is satisfied, and it dramatically misses infrastructures to evacuate worn water.

Many studies revealed the bad management of worn water and the deposits in the African cities and their impact on health and environment [13]. Abidjan has today a system of cleansing and drainage which includes a separate network of $2100 \mathrm{~km}$, a coarse pretreatment station and a repression of part of the used water towards the sea [2]. Only $40 \mathrm{PC}$ of the population of Abidjan profit from an access to the collective cleansing [10]. In the district of Abobo, selected for the study and precisely in the suburb of Avocatier-agnissankoi the cleansing sector is dominated by the autonomous cleansing systems, principal sources of diffuse and not easily controllable pollution. The dysfunctions of solid and liquid wastes cleansing systems are perceptible in the entire district. Worn water stagnates in empty spaces, roadways and drains. Muds of draining are rejected into the nature without treatment and constitute a significant threat for the soil and the phreatic nap. This study was undertaken to highlight the level of cleansing of Avocatier-agnissankoi by the cartography of the management of worn water and deposit.

\section{Material and Methods}

\subsection{Presentation of the zone of study}

The suburb ofAvocatier-agnissankoi is located at Abobo, one of the districts of the region of Abidjan. AvocatierAgnissankoi extends on 282 ha between the latitudes $05^{\circ} 26$ $04^{\prime \prime}$ and $05^{\circ} 27^{\prime} 04^{\prime \prime} \mathrm{N}$ and longitudes $04^{\circ} 01^{\prime} 04$ " and $04^{\circ} 02^{\prime}$ 06". It is limited in the North-East by the suburb of Akeikoi, in South-east by the suburb of Abobo Nord-SETU, and finally it is limited in the North by a large pit which separates it from the district of Anyama (Figure 1). The zone of study counts 6 suburbs which are:Belle-Cité (BC), Depôt 9, Quartierperdu, Chateau, Ayébi and Agnissankoi. 
International Journal of Science and Research (IJSR)

ISSN (Online): 2319-7064

Index Copernicus Value (2016): 79. 57 | Impact Factor (2015): 6. 391

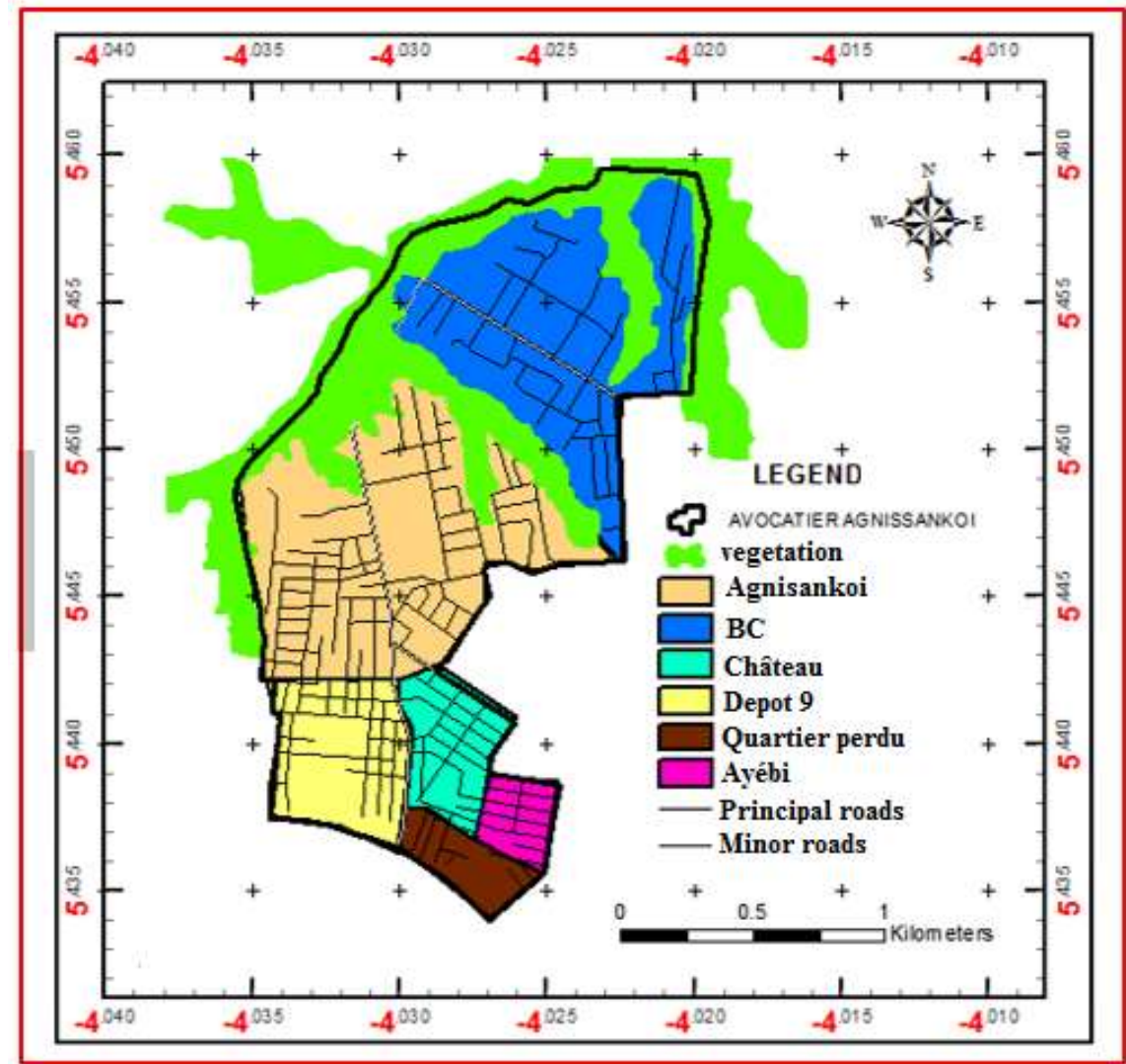

Figure 1: Chart of the suburb of Avocatier-Agnissankoi

Avocatier-Agnissankoi profits from a wet tropical climate including a great rainy season from May to July and a small rainy season from September to November. Each year, rainfalls are on average of $1744 \mathrm{~mm}$. A difference of 440 $\mathrm{mm}$ is recorded between the wettest month (August) and the driest month (January). The percentage of humidity is 80PC. The annual average temperature of theeast zone is $25,8^{\circ} \mathrm{C}$. The limit values are of $23,5^{\circ} \mathrm{C}$ for the minima and $27,2^{\circ} \mathrm{C}$ for the maxima.

\subsection{Geological and hydrogeological context}

The zone of study belongs to the sedimentary basin of the Continental Terminal (southern of the country), and primarily consists of clayey and stone sands dating from Quaternary, precisely of the Pliocene [19]. This area belongs to theknown zone of the "high plateaus". The underground water nap supplied with rainfalls is contained in fine sands, coarse sands and sometimes average sands [14].

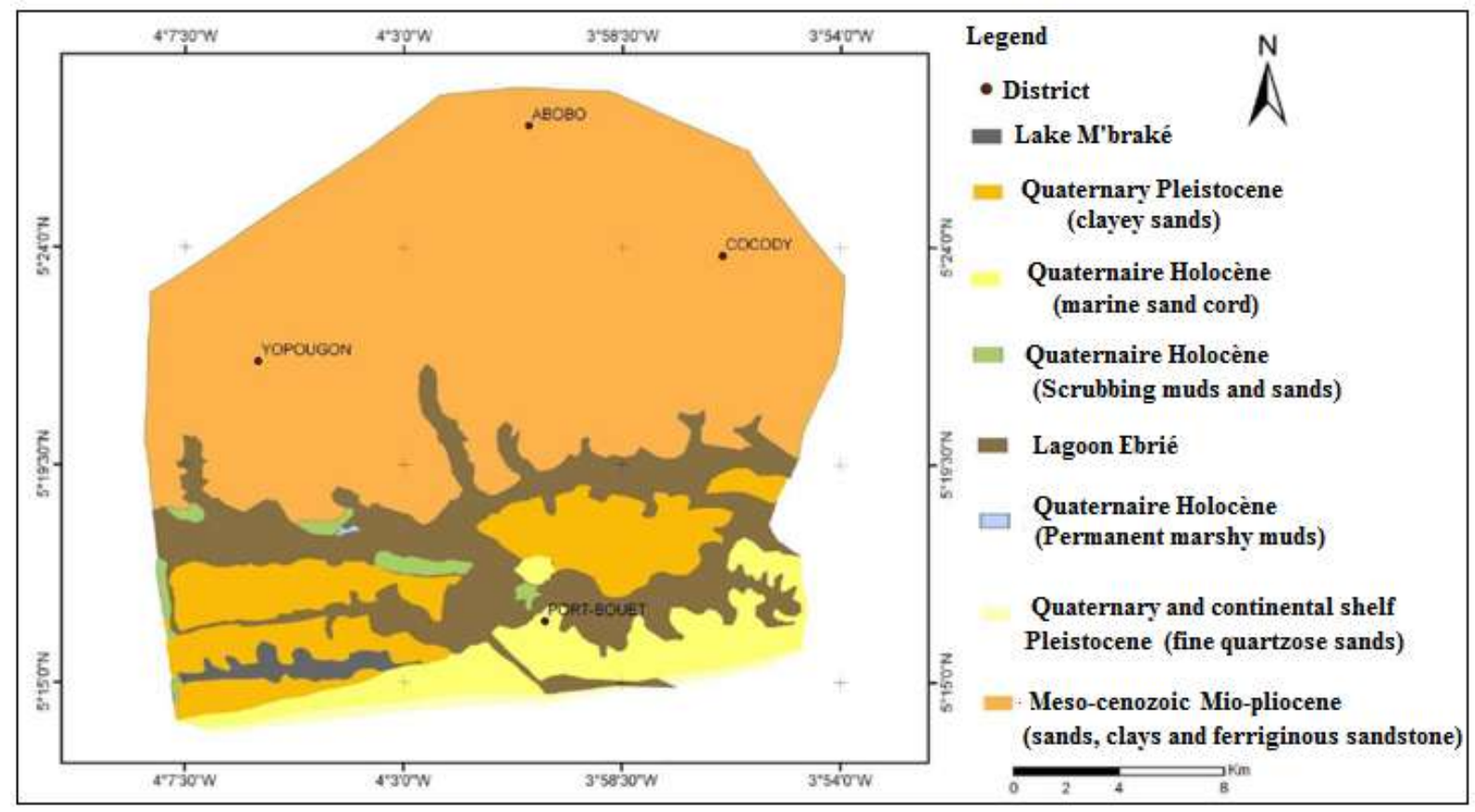

Figure 2: Geological map of the region of Abidjan.

Volume 6 Issue 12, December 2017 www. ijsr. net

Licensed Under Creative Commons Attribution CC BY 


\section{International Journal of Science and Research (IJSR) \\ ISSN (Online): 2319-7064}

Index Copernicus Value (2016): 79. 57 | Impact Factor (2015): 6. 391

Avocatier-Agnissankoi rests on a soil resulted from the sedimentary formations, of ferralitic type [15]. These sedimentary formations have anargil sandy texture suggested to erosion. Indeed, high rainfall and the effect of the climate support the intense deterioration of the ferralitic rocks.

\subsection{Material of Study}
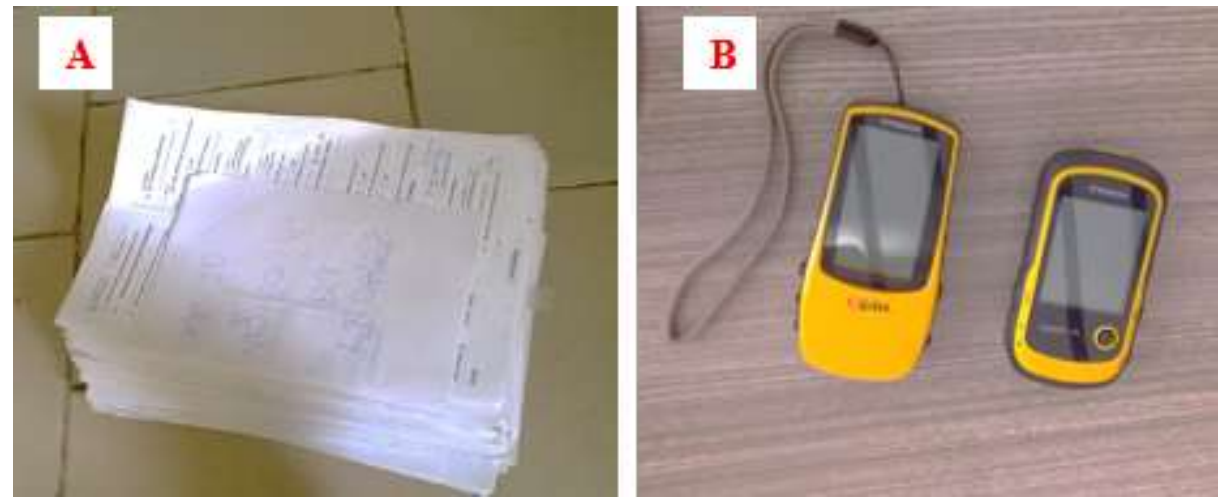

Figure 3: Surveyed Cards (A); Garmin Etrex10 GPS (B)

The correction and analysis of the data were carried out with three (3) softwares.

Sphinx v. 5. 1. 0. 7:It was used for the dataof the survey acquisitionand analysis,

Excel 2016:It was used for the correction of the data of the survey,

Easy GPS: For the importation of the coordinates emitted by the GPS and with their correction resulting from a wrong handling of the GPS or a loss of signal.

Data analyzing also need the use of the present software's:

Expert Choice 2000:Software specialized in Analytical Hierarchy Process (AHP). It allows us to treat the question of the multicritera analysis of our study, ArcGIS and QGIS were used for the design of the basic layers and to generate the charts of the sites.

\subsection{Methods}

The method adopted for the cartography of theworn water and the deposit management followed the stages of: identification of the decision criteria, the classification and standardization of these criteria for the development of the indicators in accordance with the objectives to be reached and finally the weighting of the criteria and their aggregation according to the Analytical Hierarchy Process (AHP). The Analytical Hierarchy Process (AHP) developed by [17] consists in determining the weighting coefficients of the various criteria and indicators to be applied to the charts of the sites. The choice of the Analytical Hierarchy Process (AHP) was justified mainly by its simplicity, its facility of comprehension to solve a large range of non-structured problems, its flexibility and its capacity to bring closer the quantitative and qualitative criteria within the same decision-making [5].

\subsection{Identification of the decision criteria}

It is a question of identifying the criteria and of setting up the sub-criteria which will be used for the development of the card of survey which will allow determining the impact
The collect of the data was carried out by a survey near the inhabitants (houses) of Avocatier-Agnissankoi. This stage required the use of survey cards, a Garmin Etrex10 GPSto determine the geographical locates of the surveyed houses, a telefon camera with resolution of 5. 0 MP. On the whole 642 houses were surveyed. of the management of worn water and deposit (GEUE) on health and the environment. The selected sub-criteria are houseswater drainage (EEM), the destination of the water of the valves (DEV), the mode of draining (MANDELEVIUM) and the specific problems of cleansing (PSA). The combination of these sub-criteria permit to obtain the hierarchical structure of the project (figure 4).

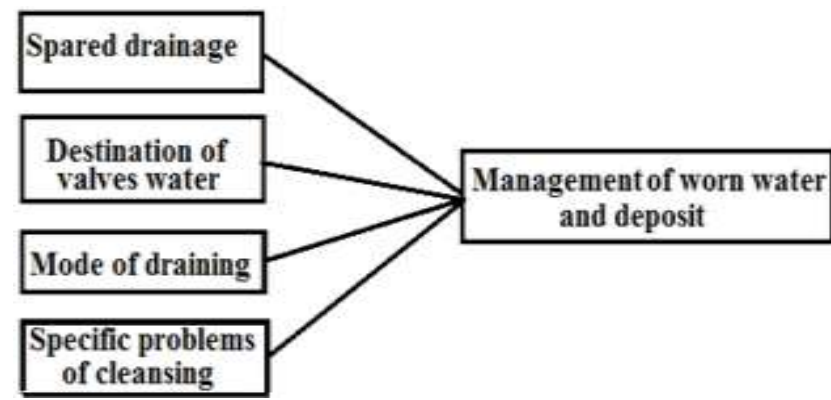

Figure 4: Hierarchical structure of the project

\subsection{Comparison pairwise}

The comparisons pairwise are carried out on the basis of scale of comparison developed by [17](Table 1).

Table 1: Scale of comparison [17]

\begin{tabular}{|c|c|}
\hline $\begin{array}{c}\text { Verbal and numerical expression of the relative } \\
\text { importance of a criteria compared to another }\end{array}$ & Notes \\
\hline Even importance & 1 \\
\hline A little more significant & 3 \\
\hline More significant & 5 \\
\hline Strongly more significant & 7 \\
\hline Extremely more significant & 9 \\
\hline A littlelesssignificant & $1 / 3$ \\
\hline Lesssignificant & $1 / 5$ \\
\hline Stronglylesssignificant & $1 / 7$ \\
\hline Extremelylesssignificant & $1 / 9$ \\
\hline
\end{tabular}

On this basis the comparisons are made pairwise using the software Expert Choice (Table 2).

\section{Volume 6 Issue 12, December 2017}




\section{International Journal of Science and Research (IJSR) \\ ISSN (Online): 2319-7064}

Index Copernicus Value (2016): 79. 57 | Impact Factor (2015): 6. 391

Table 2: Table of pairwise comparison of the sub-criteria GEUE

\begin{tabular}{|l|l|l|l|l|}
\hline & DEV & EEM & MV & PSA \\
\hline DEV & 1 & 7 & 5 & 3 \\
\hline EEM & $1 / 1.5$ & 1 & $1 / 3$ & $1 / 5$ \\
\hline MV & $1 / 5$ & 3 & 1 & $1 / 3$ \\
\hline PSA & $1 / 3$ & 5 & 3 & 1 \\
\hline & & \multicolumn{3}{|l|}{ Ratio of inconsistency $=\mathbf{0 . 0 4}$} \\
\hline
\end{tabular}

The stage of the comparison pairwise is followed by the aggregation of the factors to obtain the matrix of relative performance (Table 3). This matrix is also obtained by the Choice software.

Table 3: General matrix of relative performance

\begin{tabular}{|l|l|l|}
\hline Criteria & Sub-criteria & Weight \\
\hline GEUE 0.565 & DEV & $\mathbf{0 . 5 6 5}$ \\
\hline & EEM & $\mathbf{0 . 0 5 5}$ \\
\hline & MV & $\mathbf{0 . 1 1 8}$ \\
\hline & PSA & $\mathbf{0 . 2 6 2}$ \\
\hline
\end{tabular}

\subsection{Development of the thematic charts}

It consists in evaluating the various answers of the people questioned (surveyed) on the basis of scale in order to attribute notes to these answers. Thus we obtained 2 scales. The first rating scale reveals the impact of the management of the worn water on health and the environment (Table 4).

Table 4: Rating scale of EEM, DEV and PSA

\begin{tabular}{|c|c|c|c|}
\hline \multicolumn{2}{|c|}{$\begin{array}{c}\text { Impact of the } \\
\text { management of the } \\
\text { water used on health and } \\
\text { the environment }\end{array}$} & \multirow[b]{2}{*}{ Note } & \multirow[b]{2}{*}{$\begin{array}{l}\text { Appreciation on the } \\
\text { chart }\end{array}$} \\
\hline On health & $\begin{array}{c}\text { On the } \\
\text { environment }\end{array}$ & & \\
\hline None & None & 9 & Good \\
\hline None & Weak & 8 & Weak \\
\hline Weak & None & 7 & \\
\hline Weak & Weak & 6 & \\
\hline None & Extremely & 5 & Extremely \\
\hline Weak & Extremely & 4 & \\
\hline Extremely & None & 3 & \\
\hline Extremely & Weak & 2 & Critical \\
\hline Extremely & Extremely & 1 & \\
\hline
\end{tabular}

The second scale relates to the mode of draining which can be mechanical, manual or both at the same time (Table 5).

Table 5: Rating scale of the modes of draining

\begin{tabular}{|c|c|}
\hline Mode of draining & Note \\
\hline Mechanics & 9 \\
\hline Mechanics and Manual & 6,5 \\
\hline Manual & 4 \\
\hline No draining & 0 \\
\hline
\end{tabular}

The superposition of the thematic charts of sub-criteria EEM, PSA, DEV and MV permit to obtain the chart of the impact of the management of worn water and deposit on health and the environment. The superposition's were done while assigning to each thematic chart, the weight of the sub-criteria which it represents.

\section{Results and Discussion}

\subsection{Results}

\subsection{Description of the built and inhabited sites}

The spatial organization of the habitat emphasizes two types of occupation of the soil, namely, the individual bathes or individual dwellings occupied by only one house (35,2 PC of the sample) and the collective batheswith several houses (63,8 PC) and 1 PC for the other types of dwellings. The individual dwellings are characterized by roads in good condition and served by the urban technical networks varying from $25 \mathrm{PC}$ to $50 \mathrm{PC}$ with basic urban services of health and education. The collective bathes with several dwellings, still called "cours communes" are characterized by bathes difficult to reach (roads in bad operating condition) and the distance, even the absence of the water supply networks as well as the basic urban services. In general, the dwellings are rented by the owners who, in the greatest number of cases do not reside with the tenants.

\subsubsection{Domestic drainage (EEM)}

The domestic drainage is done in five manners (Figure 5). Worn water is poured in the street $(37,7 \mathrm{PC})$, or in open sky gutters $(27,2 \mathrm{PC})$, or in the compound $(17,1 \mathrm{PC})$, or in a pit of accumulation (14,6 PC), or in the bush (3,3 PC).

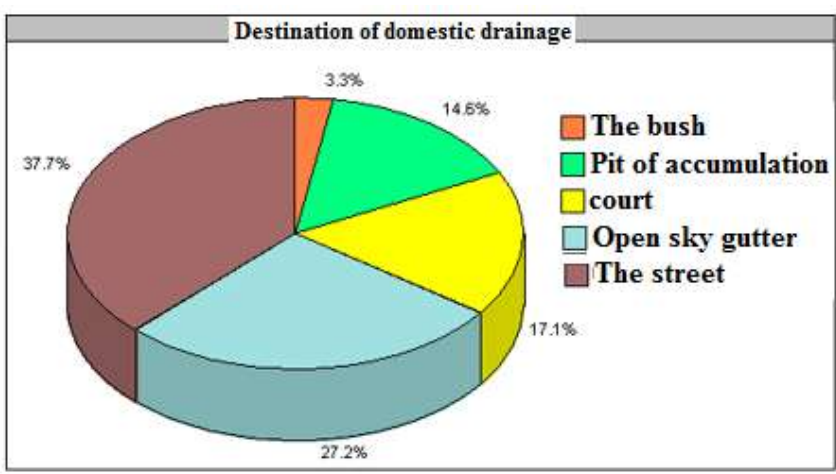

Figure 5: Destination of waste waters

The drainage of worn waters inopen sky drains (Figure 6), in the street and in the nature generates nauseous odors, the proliferation of lodgings of the vectors of diseases (mosquitos, flies, cockroaches and rodents) about which frequently the residents complain.

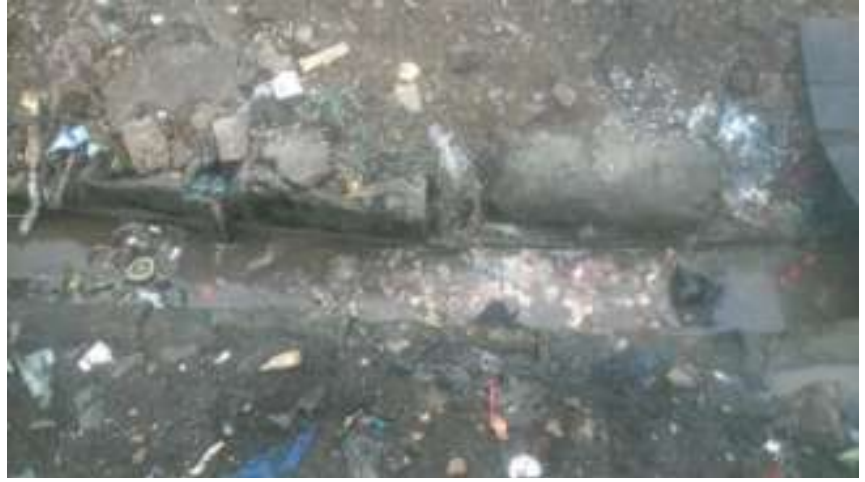

Figure 6: Discharge of waste waters in a gutter at Avocatier-Agnissankoi

Volume 6 Issue 12, December 2017 www. ijsr. net 


\title{
International Journal of Science and Research (IJSR) \\ ISSN (Online): 2319-7064
}

Index Copernicus Value (2016): 79. 57 | Impact Factor (2015): 6. 391

The bad management of waste waters permits to generate the sub-criteria chart of the drainage of houses (EEM). This thematic chart presents the impact of the management of waste waters on health and the environment (Figure 7).

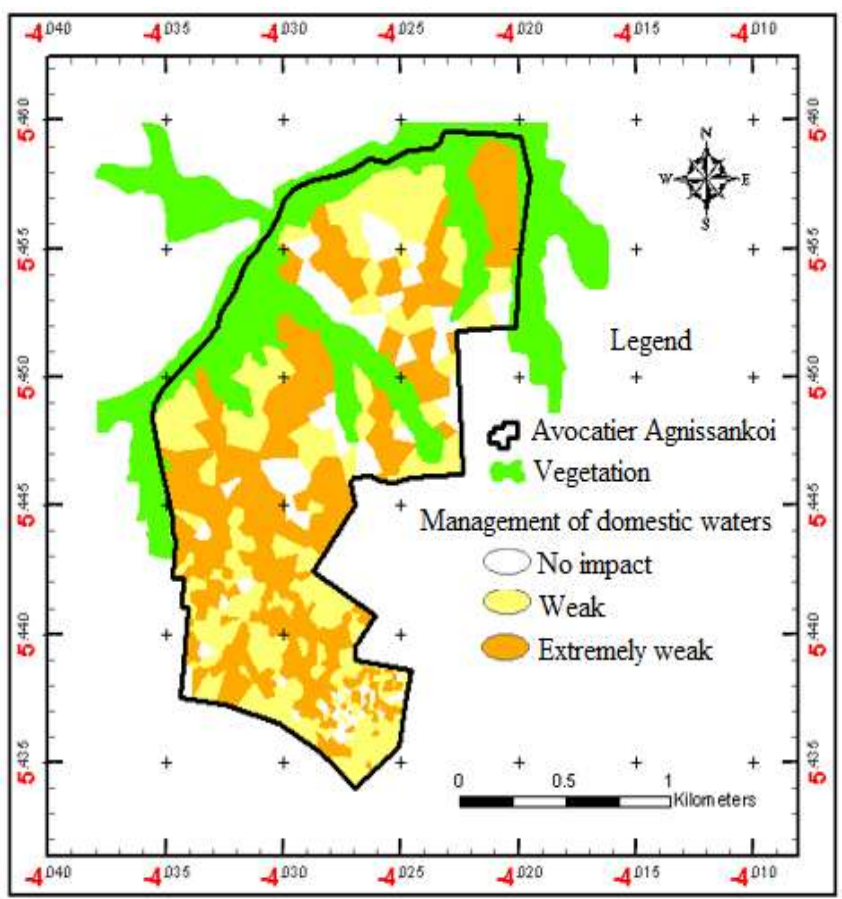

Figure 7: Impact of the management of waste waters on health and the environment

The cover of the class "Strong impact" is highest with 47,4 PC. It is most the dominant in Agnissankoisuburb. This class is followed by the class "Weak Impact" with 39, 6 PC. Only $13 \mathrm{PC}$ for "Zeroimpact ". The analysis of this chart reveals the bad management of water of houses. The problems of health, due to the non-treatment of worn water and their stagnation in the drains and free spaces are announced by 90 $\mathrm{PC}$ of the surveyed populations in the south of the zone of study. Those are conscious of the presence of germs and pathogenic microbes in worn water. They evoke diseases caused by the lack of modern infrastructures of cleansing for the drainage of houses. The stagnation of worn water in the streets is lodgings of proliferation of the mosquitos. These populations fear the malaria, the typhoid and especially the childrendiarrhea.

\subsubsection{Destination of the winnows water (DEV)}

The populations of Avocatier-Agnissankoi manage over wise the winnows water and the deposit. Indeed 57 PC of the dwellings have septic tanks in which this water is evacuated (Figure 8). The dwellings not having septic tanks connect the latrines directly to the open sky drains to evacuate their waste water.

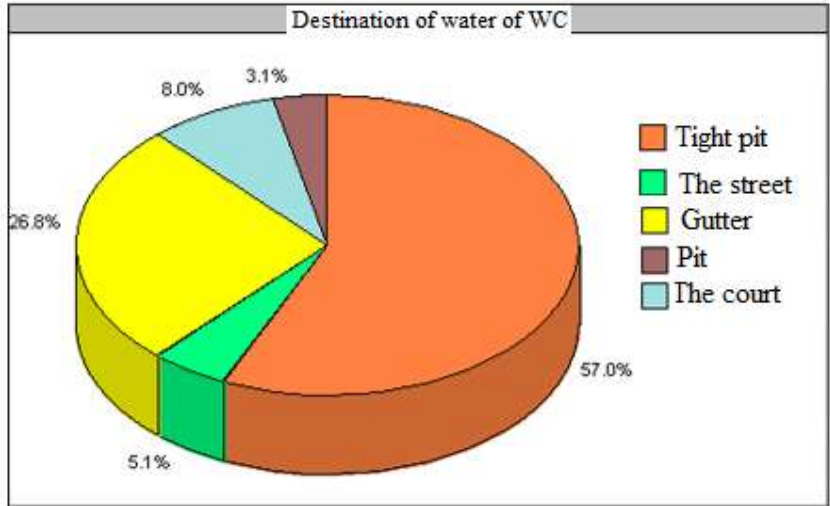

Figure 8: Destination of water of WC

The information received from the populations about the risks on health and the environment permit to generate the chart of the impact of the management of winnows water on the health and the environment (figure 9).

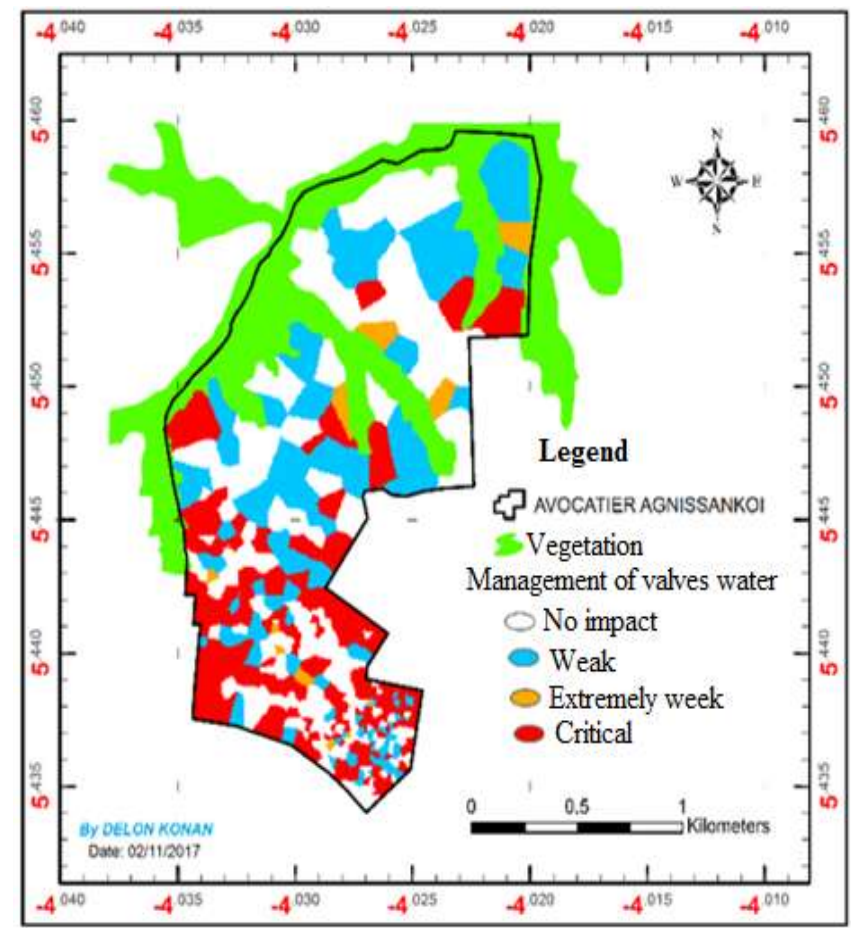

Figure 9: Impact of the Management of winnows water on the health and the environment

Winnows water are in general directed towards a septic tank or a sump and are channeled in the North of the suburb"Belle cite". That is not the case in the South (Quartier perdu, Ayébi and Dépôt 9). In these suburbs the houses use the absorbing wells for the drainage of winnows waters. These wells are not tight and constitute sources of pollution of the soils and underground naps of water.

\subsubsection{Mode of draining}

Two practices are common for the draining of the pits. It is the mechanical draining and the manual draining. These two types of draining are often complementary. 39, 6 PC of the dwellings only practice manual draining. In this type of draining, the cesspool clearers go down in the pitof accumulation for its clearing. They put then mud in a place not far from the concession (Figure 10). Mechanical

\section{Volume 6 Issue 12, December 2017}

\author{
www. ijsr. net
}




\title{
International Journal of Science and Research (IJSR) \\ ISSN (Online): 2319-7064
}

Index Copernicus Value (2016): 79. 57 | Impact Factor (2015): 6. 391

draining is practiced by $60,4 \mathrm{PC}$ of the inhabitants. But this draining is generally supplemented by manual draining.

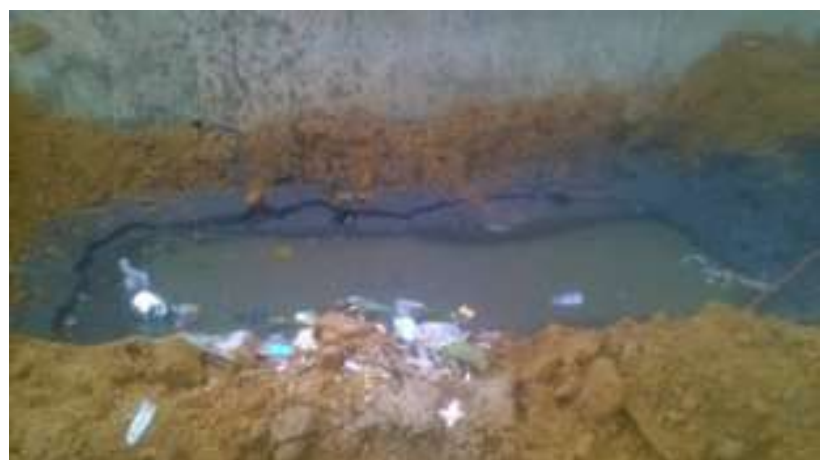

Figure 10: Hole dug to accommodate the products of a manual draining in Avocatier-Agnissankoi

\subsubsection{Specific problem of cleansing}

The specific problems of cleansing in AvocatierAgnissankoi various and are varied. The encountered problems are the absence of open sky drain to collect rainwater. That involves floods and stagnation of rainwater. With that is added the lack of infrastructures of modern cleansing to collect winnows water. The cleansing of the deposit is carried out in great majority by non-returnable traditional latrines whose pit carried out by shaft sinkers of fortune generally reaches the nap of water and constitutes a risk of microbiological contamination of ground waters. The recurring problem mentioned by the inhabitants is the flow of winnows water (with persistent odors) coming from the full pits towards the dwellings.

\subsubsection{Management of worn water and deposit (GEUE)} The balanced superposition of the four thematic charts of sub-criteria (EEM, PSA, MANDELEVIUM and DEV) of the GEUE gave the following thematicchart (Figure 11).

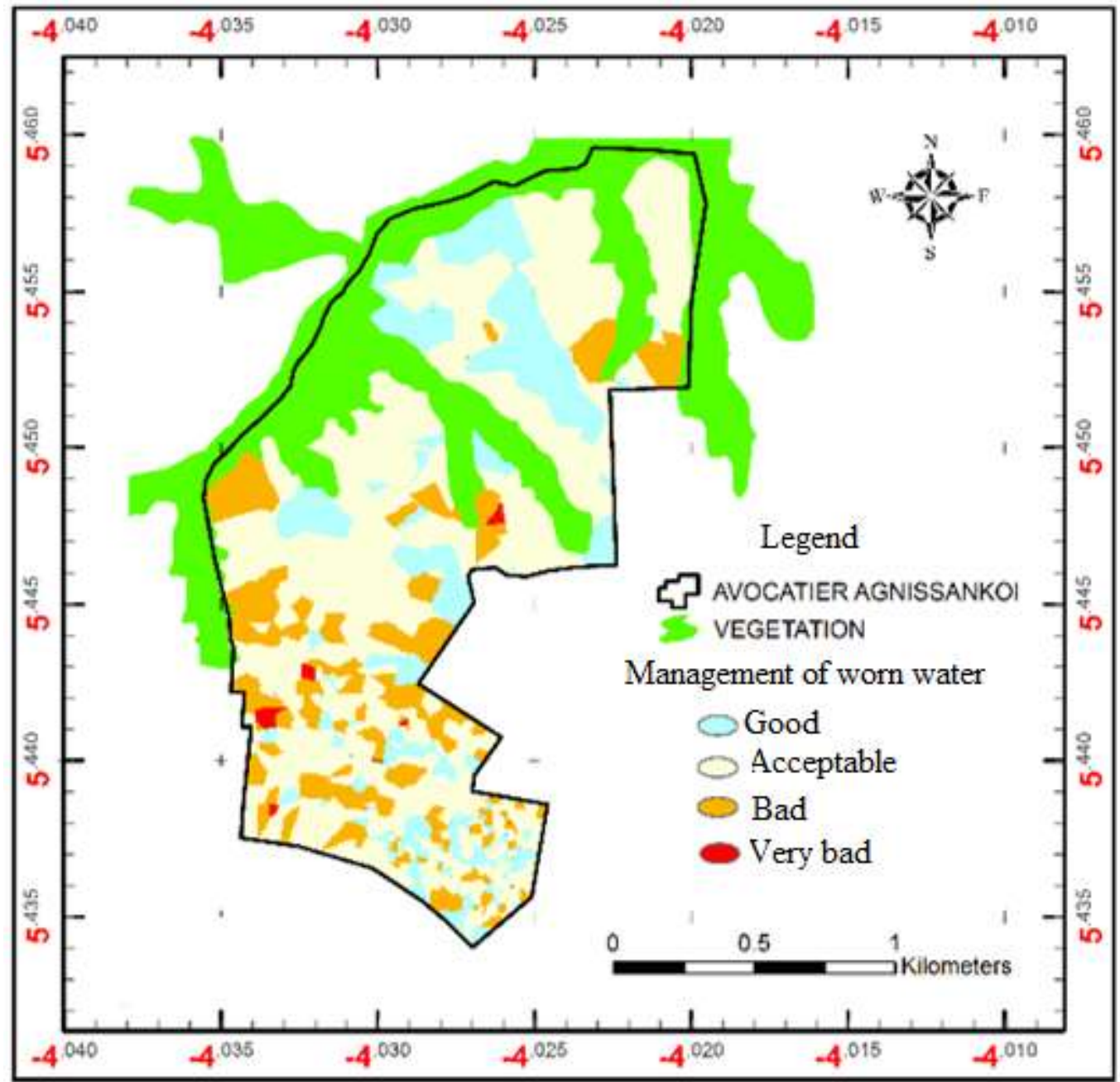

Figure 11: Impact of the Management of worn water and excreta's on health and the environment

The chart presents four (4) classes. The "Good" class represents the zones in which worn water is managed in order not to be a danger for health and the environment. The "Acceptable" classes, "Bad" and "Very bad" covers the zones with an impact on health and the environment going respectively from weak to very weak. One meets these beaches in the South of the zone of study. The suburb BC (Belle cité) and the North of Agnissankoi present a good and acceptable management of their worn water. The South is dominated by the "bad"class.

\section{Discussion}

The Geographic Information System (GIS) and the Analytical Hierarchy Process (AHP) present many assets, because they give an undeniable contribution to the

\section{Volume 6 Issue 12, December 2017}

\author{
www. ijsr. net
}




\section{International Journal of Science and Research (IJSR) \\ ISSN (Online): 2319-7064}

Index Copernicus Value (2016): 79. 57 | Impact Factor (2015): 6. 391

management of worn water and the rational decisionmakings. The GIS and the AHP are tools for cartography allowing the combination of several parameters considered ready by its originator to account for the studied phenomenon [3]. The validity of the GIS is thus directly related to the choice of its initiator for the classification of the various parameters used [4]. The Analytical Hierarchy Process (AHP) methods of assistance to the decision were used by many authors $[4,7]$. They allowed the cartography of the zones favorable to the establishment of large flow drillings $[\mathbf{1 8}, \mathbf{7}]$ and selection of better sites of waste storage $[4,16,9]$. The cartography of the management of worn water and the excreta of Avocatier-Agnissankoi reveals that the level of cleansing decreases from the North towards the South of the zone of study. This report in the North could be explained by the fact that the suburb BC (Belle cité) is a new site in full construction. The population is less dense there and the houses are modern and new. Thus contrary to the other suburbs, "Belle Cité" does not present the features of a precarious and spontaneous suburb. The suburbs of the south as for them are populated and concentrate the majority of the population. Also, in connection with the demographic factor, the South is the zone in which one meets the most commune dwellings. The houses of low standing [8], are old and agglomerated without clearly definite directing diagram. The waste waters are poured in open sky drains which are conceived to collect rain water. These anarchistic discharges allow the air pollution with the release of nauseous odors. Similar results were obtained by [20] in three cities of subsaharan Africa.

The in salubrity and the stagnation of the water in the streets and the gutters become places of production of the larvae of mosquitoes which are vectors of malaria [20]. The absence of infrastructures of cleansing in AvocatierAgnissankoiallows the deterioration of the of life level. With that is added the destination of winnows water and the bad management of muds of draining. Muds of draining contaminate the nap and the water levels, making their water inapt for consumption (Morel 2003). According to [6], badly managed waters and deposits constitute a source of obvious diseases, multiplying the risks of diarrheas, typhoid fever or dysentery.

The studies of [1] evaluate the parasitological contamination of the domestic worn water collected and purified at the station of activated sludge of Cambérène. These studies reveal a strong parasitic load of worn water.

\section{Conclusion}

The data received from the dwellings reveals the level of cleansing of Avocatier-Agnissankoi. Water of houses is poured in the street $(37,7 \mathrm{PC})$, in open sky gutters with $(27,2$ $\mathrm{PC})$, in the courses of the dwellings (17,1 PC), in accumulation pits (14,6 PC), or in the bush (3,3 PC). Winnow waters is evacuated in $57 \mathrm{PC}$ of the houses by nontight septic tanks. These pits are quarries by two modes of draining (manual and mechanical). The residue of these draining's rejected without treatment in the nature. The specific problem of cleansing in Avocatier-Agnissankoi is the lack of infrastructures of modern cleansing to collect worn water and the absence of structures of treatment of all these effluents. It is advisable to work out strategies of sensitizing to hygiene and the cleansing near these populations in order to help them with better forming of the individual cleansing (autonomous). And the political authorities must be implied so that these populations have access to the modern infrastructures of cleansing.

\section{References}

[1] Akpo Y, Sawadogo G. J, Degnon R. G. (2013). Évaluation de la contamination parasitologique des eaux usées domestiques collectées et traitées à la station d'épuration de Cambérène (Dakar). Journal of Applied Biosciences 69: 5449-5455

[2] C2D. (2017). Contrat de Désendettement et de Développement. Fiche projet Côte d'Ivoire CCI 1532. $2{ }^{\text {ème }} \mathrm{C} 2 \mathrm{D}$ eau et assainissement. $2 \mathrm{p}$.

[3] Dibi B. , Inza D. , KoffI K. , Soro N. , Kouame K. J. et Savane I. (2007). Evaluation et cartographie de la vulnérabilité à la pollution en aquifère confiné selon la méthode DRASTIC: Cas de La région d'Aboisso, SudEst de la Côte d'Ivoire. European Journal of Scientific Research, 18 (3) : 500-513.

[4] El Morjani Z. (2002). Conception d'un système d'information à référence spatiale pour la gestion environnementale ; application à la sélection de sites potentiels de stockage de déchets ménagers et industriels en région semi-aride (Souss, Maroc). Thèse de doctorat, Université de Genève. Terre et Environnement. Vol. 42, 300 p.

[5] El Amraoui M S, Rouchdi M, Bouziani M, El Idrissi A. (2017). Intégration du SIG et de l'analyse multicritère pour l'aide dans la planification urbaine : Etude des cas de la province de Khemisset, Maroc. Papeles de geografia, 63, http://dx. doi. org/10. 6018/geografia/2017/280211

[6] Gnaboa $T$ (2004). Comment traiter les eaux domestiques des fosses toutes eaux. Cas de yamoussoukro, Cotonou, Ouagadougou. Mémoire de DEA. Engref-ENPC, Paris, France, 47 p.

[7] Jourda J. P. , Saley M. B. , Djagoua E M, Kouamé K. J. , Biémi J. et Razack M. (2006). Utilisation des données ETM+ de Landsat et d'un SIG pour l'évaluation du potentiel en eau souterraine dans le milieu fissuré précambrien de la région de Korhogo (Nord de la Côte d'Ivoire) : Approche par analyse multicritère et test de validation. Revue Internationale de Télédétection, 5(4): 339-357.

[8] Kaba I. (2015). Qualité de vie et sante dans un quartier à habitat indigne de la ville d'Abidjan (Côte d'ivoire): Rôle de l'assainissement dans ce débat écologique. European Scientific Journal 11(29): 357-368.

[9] Kouame K. J (2007). Contribution à la gestion intégrée des ressources en eaux (GIRE) du District d'Abidjan (Sud de la Côte d'Ivoire) : Outils d'aide à la décision pour la prévention et la protection des eaux souterraines contre la pollution. Thèse unique de doctorat, Université de Cocody, $225 \mathrm{p}$.

[10] MINSEDD. (2017). Document de présentation de la thématique: Eau et Assainissement. Ministère de la salubrité, de l'environnement et du développement durable. Côte d'Ivoire. 6p.

\section{Volume 6 Issue 12, December 2017}




\section{International Journal of Science and Research (IJSR) \\ ISSN (Online): 2319-7064}

Index Copernicus Value (2016): 79. 57 | Impact Factor (2015): 6. 391

[11] Morel A. (2003). Gestion domestiques des eaux usées et des excrétas : Etude des pratiques et comportement, des fonctions de demande, de leur mesure en situation contingente et de leur opérationnalisation, PDM-pSEau, 197 p.

[12] N'Gnikam E. , Mougoue F. et Tietche F. (2007). Eau, Assainissement et impact sur la santé: étude de cas d'un écosystème urbain à Yaoundé. Actes des JSIRAUF, Hanoi, 13p.

[13] Niang S. (1995). Evacuation et traitement des eaux usées urbaines de Dakar: bilan de la situation, comportements des populations et perspectives d'avenir: premières contributions pour le choix d'un système de traitement des eaux usées urbaines de Dakar par Mosaïques Hiérarchisées d'Ecosystèmes Artificiels. Thèse de $3^{\text {ème }}$ cycle en Sciences de l'Environnement : Dakar ; 90.

[14] ONU-Habitat. (2012). Côte d'Ivoire : Profil urbain d'Abobo. Nairobi, Editions UNON. 28p.

[15] Perraud A. (1971). Le milieu naturel de Côte d'Ivoire : les sols. Mémoire de l'ORS TOM (France) n50, pp 269-391.

[16] Roy B. (1995). Méthodologie multicritère d'aide à la décision. Economica, xxii, Paris, 423 p.

[17] Saaty T. L. (1977). A scaling method for priorities in hierarchical structures. Journal of Mathematical Psychology, 15 : 234-281.

[18] Saley M. B. (2003). "Système d'information hydrogéologique à référence spatiale, discontinuité pseudo- image et cartographie thématique des ressources en eau de la région semi-montagneuse de Man (Ouest de la Côte d'Ivoire)". Thèse unique de doctorat, université de Cocody. 209 p.

[19] Tagini B. (1971). Esquisse structurale de la Côted'Ivoire. Essai de géotectonique régionale. Thèse de Doctorat d'Université de Lausanne (Suisse). Bulletin, SODEMI, $\mathrm{n}^{\circ}$ 5, $302 \mathrm{p}$.

[20] Wethé J, Radoux M, et Tanawa E. (2003). Assainissement des eaux usées et risques sociosanitaires et environnementaux en zones d'habitat planifié de Yaoundé (Cameroun). Vertigo, 4 (1).

Volume 6 Issue 12, December 2017

www. ijsr. net

Licensed Under Creative Commons Attribution CC BY 